\title{
Students' use and perceptions of feedback in a paired collaborative speaking task
}

\author{
Nguyen Xuan Nguyet Truc ${ }^{1 *}$, Bui Thi Thuc Quyen² \\ ${ }^{1}$ Vietnam-USA Society English Centers, Vietnam \\ ${ }^{2}$ Ho Chi Minh City Open University, Vietnam \\ *Corresponding author: nxntruc@gmail.com
}

\begin{abstract}
ARTICLE INFO
ABSTRACT

DOI: $10.46223 /$ HCMCOUJS. soci.en.8.1.284.2018

Received: October $31^{\text {st }}, 2018$

Revised: December $6^{\text {th }}, 2018$

Accepted: December $6^{\text {th }}, 2018$

Keywords:

collaboration, feedback, paired conversation

Learner-centeredness is an integral part of Communicative Language Teaching (CLT) and paired conversations are promoted by this method because it is considered to effectively increase the student talking time. In paired conversations, instead of being merely interlocutors during their speaking activities, students are expected to initiatively assist each other's performances by exchanging feedback and comments. This study examined 28 intermediate students on how they gave their partners feedback during a paired collaborative speaking task. It also investigated their perceptions of exchanging feedback. Observation and semistructured interviews were employed for data collection. A mismatch between their viewpoints and actual performances was found. The interview analysis suggests that the students were wellaware of the roles and benefits of giving and receiving feedback. Meanwhile, the empirical data collected from the observation scheme shows that only a modest number of feedback instances, particularly corrective feedback, were actually given by the students. This mostly resulted from the students' lack of proper strategies and skills in giving feedback and their fear of losing their partners' faces.
\end{abstract}

\section{Introduction}

The history of language teaching has experienced many changes. Around the world, many teachers have shifted their method from teacher-centeredness to learner-centeredness, where learners play an important part in not only their own learning but that of their classmates as well. With learner-centeredness, like the teacher, learners have become a source which their peers can also rely on. In other words, the feedback learners receive from their peers has become a crucial component of a nowadays language classroom. So far, though research has proved that learners can provide each other with feedback (Fujii \& Mackey, 2009; Zhao \& Bitchener, 2007) and student-student interactions can lead to more uptake than teacher-student dialogues (Ellis, 2009; Lyster \& Ranta, 1997), only a small number of classroom studies have investigated student-generated feedback in detail. 


\section{Feedback}

Feedback is any kind of information that learners receive about their performance. This can be corrective feedback which focuses a learner's attention on errors, or it can be noncorrective, in the form of praise or encouragement, for example (Kerr, 2017). To Łęska (2008), feedback is information concerning the comprehension and reception of the speaker's message given by the listener while for Askew and Lodge (2000, p. 6), feedback is "a judgment about the performance of another" and the purpose of giving and receiving feedback is to adjust the subsequences performances of the recipient. Feedback has been evidenced as beneficial to learners in a number of studies (Ellis \& Shintani, 2013; Hall, 2016; Lyster, Saito, \& Sato, 2013). More importantly, it has been found being more effective than teacher feedback in developing learners' speaking performance in Lynch (2007). Lynch concluded that learner-initiated feedback provokes more talk among learners about language, as well as greater, deeper cognitive processing activities, which may benefit learners more than teacher-initiated feedback does in such tasks (2007).

\section{Student-generated feedback as peer feedback and peer correction}

In this article, feedback is supposed to be a combination of peer feedback and peer correction. By peer feedback, the researcher means "a communication process through which learners enter into dialogues related to performance and standards" (Liu \& Carless, 2006). Peer correction indicates when one learner helps another learner to correct his/her (another learner) mistakes. The main advantages of this correction are learners' involvement in face to face interaction and their cooperation with each other; they become less independent on teachers and more confident in themselves (Méndez, Cruz, \& del Rosario, 2012).

\section{The benefits of peer interaction and feedback}

One way to promote student feedback is creating chances for peer interaction such as using paired collaborative speaking tasks. Peer interaction provides learners with opportunities to give and receive feedback (Adams, 2007; Sato \& Lyster, 2012).

This goes well with the belief in social interaction proposed by social constructivists, such as Vygotsky (1978), (Von Glasersfeld, 1991). An individual's knowledge of the world is bound to personal experiences and is mediated through interaction (language) with others (Von Glasersfeld, 1998). By actively providing feedback, students can at the same time scaffold and construct their own knowledge (Reynolds, 2009). The teacher then no longer remains the source of information since they can seek help and knowledge from their friends or partner (Gielen, Peeters, Dochy, Onghena, \& Struyven, 2010).

When students initiatively giving and receiving feedback, they become more autonomous in their own learning and less dependent on their teacher (Roskams, 1999). They become active by putting in the effort to give quality feedback to their peers (Kaufman \& Schunn, 2011) and by assessing the accuracy of the feedback they receive and decide whether to accept or reject it. Therefore, both receiver and giver of feedback can be beneficial (Smith, 2009). Furthermore, peer feedback is also a social practice that affects student's behavior and motivation (Koka \& Hein, 2006; Martin \& Jacobs, 1980; Mutch, 2003). By giving their partner feedback, students can learn interpersonal skills through the language practice of giving and receiving feedback (Boud \& Falchikov, 2006). They also learn how to manage the different types of behavior and conflict during the discussion (Roskams, 1999; Rubin, 2006). This means 
the process of discussion permits revision of ideas and the construction of new knowledge in a low anxiety context as students find it easier to accept criticism from their peers (Black, Harrison, Lee, Marshall, \& Wiliam, 2004; Lu \& Law, 2012).

However, it should be noted that during fluency-based tasks many students are reluctant to offer feedback on their peers' language performance and, when it is offered, students are probably less attended to it than feedback that comes from a teacher (Kerr, 2017). Lyster et al. (2013) mentioned that student feedback tends to be underestimated by their peers due to their low language competence which also makes them reluctant to offer feedback. Additionally, there is a risk that corrective feedback will break up the flow of communication and encourage students to focus on accuracy at the expense of fluency and complexity (Pili-Moss, 2014).

\section{Types of feedback}

Long (1996) has stated about negative and positive feedback: negative feedback points out to the students that their utterances are faulty in some way, and all feedback instances that are not negative are positive.

\section{Positive feedback}

Positive feedback affirms the correctness of the content and linguistic form of a learner utterance. It may "signal the veracity of the content of a learner utterance or the linguistic correctness of the utterance" (Ellis, 2009, p. 3) by giving praises or complements such as "Good", "Yes", "alright", "Yes, an excellent answer" (Richards \& Lockhart, 1994). Ellis (2009) also states that positive feedback provides effective support to learners and enhances their motivation (Ellis, 2009; Wheldall \& Merrett, 1984). However, positive feedback has received little attention, partly because "discourse analytical studies of classroom interaction have shown that the teacher's positive feedback move is frequently ambiguous" (Ellis, 2009, p. 3). Little research has drawn on the students' use of positive feedback.

\section{Negative feedback (Corrective feedback)}

Negative feedback, on the other hand, signals the lack of veracity and linguistic deviance in the learner's utterance. In other words, it is called corrective feedback (CF). Richards and Schmidt (2010) explain that corrective feedback includes some strategies a teacher or a more advanced learner use to correct errors in a learner's speech directly (i.e., teacher provides the correct form) or indirectly (i.e., teacher points out the problem, then the learner tries to correct it if possible). Ellis, Loewen, and Erlam (2006) classify corrective feedback in different terms which are implicit or explicit feedback. In the former, there is no overt indicator that students have committed an error, while in the latter, there is.

Ellis and Sheen (2011, p. 593) encapsulate a cohesive taxonomy of corrective feedback. 


\section{Table 1}

A taxonomy of corrective feedback strategies (Ellis, 2009, p. 8)

\begin{tabular}{lll}
\hline & Implicit & Explicit \\
\hline \multirow{2}{*}{ Input-providing } & Recast & Explicit correction \\
Output-prompting & Repetition & Metalinguistic explanation \\
& Clarification request & $\begin{array}{l}\text { Elicitation } \\
\text { Paralinguistic signal }\end{array}$ \\
\hline
\end{tabular}

Source: The researcher's data analysis

Ellis (2009, p. 9) also suggested types of corrective feedback as follows:

1. Recast: The corrector incorporates the content words of the immediately preceding incorrect utterance and changes and corrects the utterance in some way (e.g., phonological, syntactic, morphological or lexical).

S: *Why you don't like Marc?

T: Why don't you like Marc?

2. Repetition: The corrector repeats the learner utterance highlighting the error by means of emphatic stress

$\mathrm{S}: *$ I have three new toys.

T: Three new toys?

3. Clarification request: The corrector indicates that he/she has not understood what the learner said

T: How often do you wash the dishes

S: Fourteen.

T: Excuse me. (Clarification Request)

S: Fourteen.

T: Fourteen what? (Clarification Request)

$\mathrm{S}$ : *Fourteen for a week.

T: Fourteen times a week? (Interrogative Recast)

S: Yes. Lunch and dinner.

4. Explicit correction: The corrector indicates an error has been committed, identifies the error and provides the correction

S: *The dog run fastly.

T: "Fastly" doesn't exist. "Fast" does not take - ly. You should say "quickly".

5. Elicitation: The corrector repeats part of the learner utterance but not the erroneous part and uses rising intonation to signal the learner should complete it. 
$\mathrm{S}: *$ My father cleans the plate.

$\mathrm{T}$ : (Excuse me), he cleans the $?$

S: Plates?

6. Paralinguistic signal: the corrector uses a gesture or facial expression to indicate that the learner has made an error.

$\mathrm{S}: * \mathrm{We}$ look at the people yesterday.

T: What's the ending we put on verbs when we talk about the past?

S: /e-d/

\section{Previous study}

Foster and Ohta (2005) found evidence of learners paying attention to linguistic forms in both their own output and that of their peers. During conversations, the learners also expressed interest in each other's talk and encouraged each other to continue. Similarly, Ohta (2000) undertook an empirical study with college-level learners of Japanese as a foreign language to investigate how they assisted each other's performance in the classroom. She found that students not only asked for but also offered feedback to scaffold each other's performance. Further, she found that even less proficient peers were able to support more proficient students with feedback. Most interestingly, she discovered that learners seemed sensitive to each other's ZPD, as they knew when to keep silent and wait for peers to reformulate their utterances, and when to break the silence with the provision of feedback.

Preston and Todd-Mancillas (1985) gave some insights into what students find to be effective oral feedback. They recorded speeches given by students along with the instructor's oral feedback. Students were asked what aspects of the feedback they find helpful and whether some of the feedback would increase or decrease their self-esteem. Personally, directed feedback and feedback that focuses on certain features of the speech was found to be most helpful by the students. Complements were said to make them feel good, but not significantly improve their skills. Importantly, this study shows that students want to receive more specific feedback which feedbacks that they can relate with or understand.

In the Vietnam context, however, there is a dearth of the published discussion by ESL/EFL practitioners on students' use and perception of feedback in their speaking task. Most research works have dominantly been done on teachers' feedback on students' speaking performances or students' peer feedback on their writing task.

\section{Research gap}

Those previous studies, however, were mostly conducted to investigate students' perception of using feedback but did not clearly show how frequently they provide peer feedback as well as their preferred types of feedback. Importantly, the focus of this study is considered as a fertile area of research that has not been comprehensively explored in Vietnamese context. Therefore, this research was expected to fill the gap of previous studies as well as contribute more insights to the current English teaching and learning environment in Vietnam by revealing types of oral corrective feedback most frequently employed by the students and how they actually used feedback to assist their peers' performances. This study aimed to answer the three following questions: 
1/ What percentage of student errors was given feedback by their partners?

2/ What types of feedback did the students usually give to their partners?

$3 /$ What are their perceptions of giving and receiving feedback?

\section{Method}

This study is mainly qualitative in its design with the use of an observation scheme and a semi-structured interview as data collection instruments. The participants were 28 intermediate students studying in a language center. First, the students were asked to join a paired speaking task that resembles the Cambridge Preliminary English Test (PET) speaking test part 2. Their performance was recorded and analyzed by means of an observation scheme to investigate their actual use of feedback during their talk. Then they participated in a semistructured interview to enhance further discussion and questions (Sayrs, 1998). The interview was carried out in Vietnamese, which is also the students' mother tongue. The students' names were kept anonymous.

\section{Findings and discussion}

Question 1: What percentage of student errors was given feedback by their partners?

\section{Table 2}

The comparison between the total number of feedbacks moves given by the students and that of errors detected from the observation

\begin{tabular}{|l|c|c|}
\hline & Total number & Percentage \\
\hline Students' feedback moves & $\mathrm{n}=20$ & $11,7 \%$ \\
\hline Students' errors detected & $\mathrm{n}=171$ & $100 \%$ \\
\hline
\end{tabular}

Source: The researcher's data analysis

Table 2 shows that students are reluctant to give feedback to their peers. Only $11.7 \%$ of student's errors received feedback and the other $88.3 \%$ remains ignored or undetected. This result is in line with the interview analysis shown in Figure 1 as below:

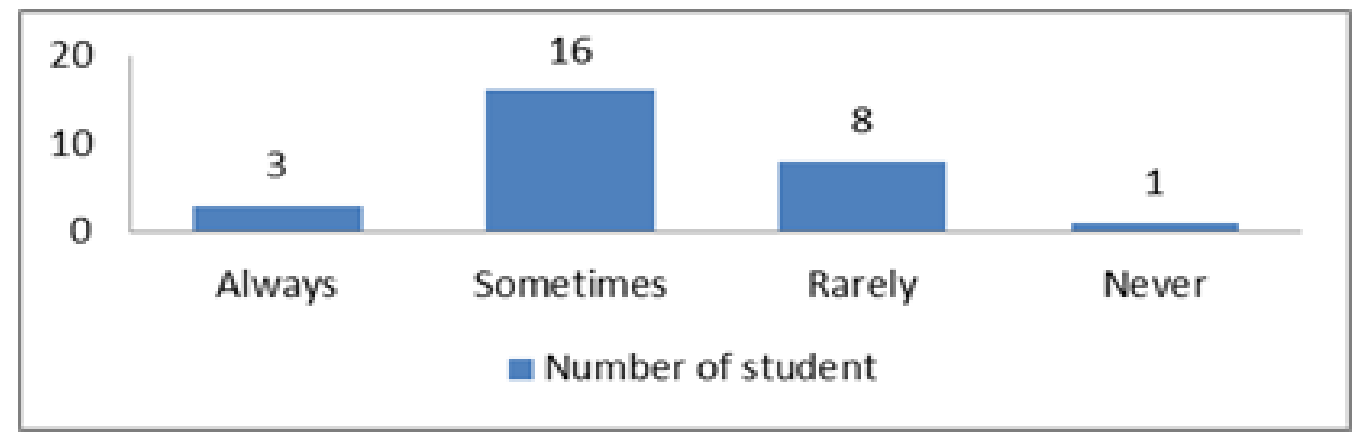

Figure 1. The frequency of correction in student practice from the interview

Although 27 over 28 students (over 95\%) admitted that they were aware of their partner making errors during their conversation, 59\% of them (16 students) sometimes corrected the errors and 27\% (8 students) chose to ignore the errors. Only 11\% (3 students) said that they 
always corrected their partners' errors. There are several underlying reasons. First, instead of interrupting their partners' talk, they could guess their partner's ideas from the rest of the conversation. Second, they believed that several errors would not affect the flow of their conversation. Finally, they were afraid of losing each other's faces. The result is similar to that of Sato (2007) and Philp, Walter, and Basturkmen (2010) (as cited in Sato \& Ballinger, 2016).

Concerning when to give feedback, 53\% of students (15 students) chose to delay their feedback until the end of the conversation in order not to disrupt the conversation flow, which is in line with (Pili-Moss, 2014). However, their intention cannot be accomplished without supports from proper strategies.

\section{Extract 1}

T: [at the end of the conversation] Do you have any comments or feedback to share with your friend?

S: No

T: Did you notice that your friend had made several errors during his (her) talk?

S: Yes

T: Why don't you share with your friend?

S: I forgot all of them.

\section{Extract 2}

T: [at the end of the conversation] Do you have any comments or sharing with your friend about her performance? Did she have any errors while she was talking?

S: Yes, I intended to share after we finished but I was so attentive to my talk so I forgot.

It is obvious that these students preferred delayed-feedback but they ended up forgetting what they were supposed to say. On one hand, the students showed that they did focus and put the effort in scaffolding their peers but it is no use without proper note-taking strategies which can be trained and guided by the teacher.

In contrast, $29 \%$ of the students ( 8 students) decided to give feedback right away since they believed that immediate feedback could prevent their partners from repeating the same mistakes later on.

Nevertheless, it is noticeable that regarding content errors, the interviewees tended to give feedback or ask for clarification immediately since the lack of content understanding could affect their conversation. 
Question 2: What types of feedback did the students usually give to their partners?

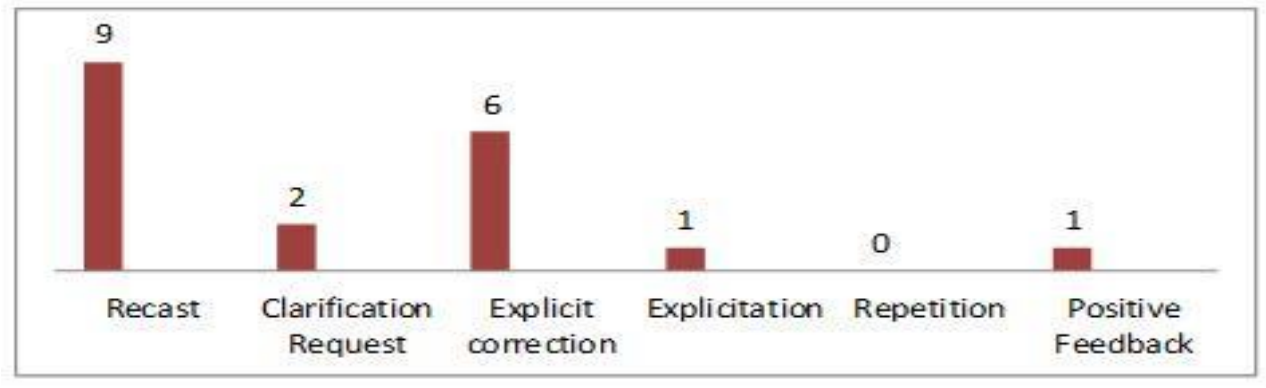

Figure 2. The frequency of feedback types used by the students in the observation

Figure 3 indicates that recast is the most frequent type of feedback (45\%). This result is in line with the interview in which $54 \%$ of students (15 students) informed that they often used recast intentionally or unintentionally during their conversation.

\section{Extract 3}

T: Look at the table here, what type of feedback do you use the most frequently?

S1: Number 1 (recast)

T: Why so? Why don't you use others?

S1: I don't know, I recognized an error and I started to correct it right away.

T: [turn to S2] so when he corrected your errors, you reformulated your sentence using your friend's correction. Do you know why your sentence is wrong?

S2: Yes

T: What was wrong?

S2: My pronunciation

This is the case in which the corrector attempted to correct his partner's pronunciation error. Unfortunately, his correction was also incorrect and his partner applied it to reformulate her own utterance without hesitation.

\section{Extract 4}

T: Look at the table here, what type of feedback do you use the most frequently?

S1: Number 1 (recast)

T: Why so? Why don't you use the others?

S1: Because using recast is simple and doesn't take time. Otherwise, I can interrupt my friend and make her forget what she is going to say.

T: [turn to S2, replay the video when S1 corrected S2's error] so when he corrected your errors, you reformulated your sentence using your friend's correction. Do you know why your sentence is wrong?

S2: He pointed out my error and I corrected it but I didn't know why. 
T: Why didn't you think carefully before you self-corrected?

S2: I didn't have time and I think she (the corrector) was right, so I just repeated and continued my idea.

As can be seen, most students prefer recast since it is simple and saves time. However, as Baleghizadeh and Abdi (2010) have mentioned in their study, the student did not notice why what they had said was wrong and they just repeated the corrected words so that they could continue with what they wanted to say and get their message across. In addition, Lyster (1998) points out that recasts may be ambiguous and thus confuse the learners without guiding them to find their mistakes. The participants in this study also faced a similar situation. Apparently, recast is not an effective tool for error correction since it does not always result in comprehension. Besides, it is worth noticing that students' language competence in each pair is also a crucial factor affecting the quality and accuracy of feedback.

Question 3: What are their perceptions of giving and receiving feedback?

The answers to the first two questions have partially revealed the students' perspectives in using and giving feedback. The last question comes up with how the students assess feedback in terms of its usefulness and feedback giving manner.

\section{Table 3}

The total of feedback moves given by the students in the observation

\begin{tabular}{|l|c|}
\hline Feedback on form & $5(25 \%)$ \\
\hline Feedback on content & $15(75 \%)$ \\
\hline Total & 20 \\
\hline
\end{tabular}

Source: The researcher's data analysis

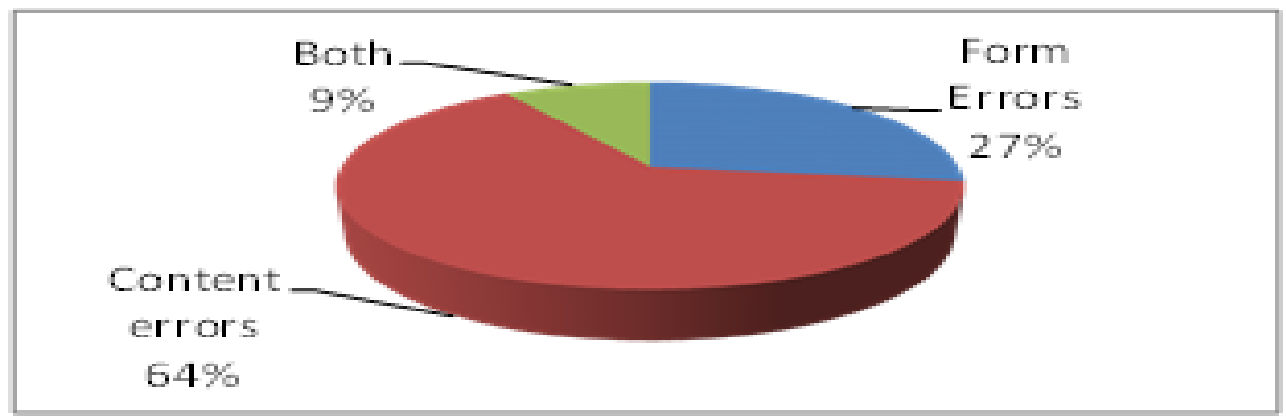

Figure 3. Students' focus on errors in the interview

As can be seen from Table 3 and Figure 3, students' focus when giving feedback is mainly on the content of the conversation and little attention has been paid to grammatical errors. $63 \%$ of students from the interview believed that they were not able to catch up with the conversation and gave responses if their partners produce lexis unknown to them. The other 
$27 \%$ of students, on the other hand, drew their attention to form errors since they were easily detected and some form errors impeded their comprehension.

Importantly, in the interview, over $95 \%$ of students agreed that both giving feedback to their partner and receiving feedback from them are helpful for their learning for two outstanding and predictable reasons. Firstly, thanks to feedback, they have insights into how their friends think about their performance from which they can adjust and improve their own learning. Secondly, to the students, giving feedback is creating a win-win chance that is beneficial to not only the receiver but also the giver as they both enhance their own learning from this process.

Finally, yet importantly, according to the students, using feedback can lead to several drawbacks and some of them even refuse to get it unless it is given at the right time in a right manner. To be specific, as mentioned above, giving sudden or too much feedback can interrupt the conversation making the students usually annoyed and distracted. Furthermore, feedback should be given in a well-mannered way to avoid embarrassment, which can negatively affect the students' motivation.

\section{Conclusion and implication}

The result of this study has shed light on how the students actually use and think of feedback during their speaking task, which remains an under-investigated area in Vietnamese context. The findings reveal that even though students are well aware of the benefits of feedback and most of them highly appreciate the exchange of feedback during their paired speaking task. Interestingly, most students rarely or occasionally provide feedback but they yearn to have feedback from their friends. Additionally, recast is the students' most frequently-used type of feedback since it was simple and time-saving to provide even though its effect has been statistically proved as minimal and ambiguous in several studies. Besides, in order not to cause any interruption during their conversation, most students agree that feedback should be given at the end of their dialogue, especially in a courteous attitude to avoid face losing. Therefore, to maintain the student's self-confidence and motivation as well as to make them become more engaged in an effective feedback process, the teacher should conduct some training on feedback strategies in the classroom and have them practice it in every speaking activity. The teachers could assist by guiding the students on the ethics of giving feedback and counseling students who might be disrespectful or disruptive during the feedback process (Reynolds, 2009). In addition, peer allocation is also highlighted in this study. As (Vygotsky, 1978) suggests that teachers can create effective pair work by using cooperative learning exercises where students are able to work with a partner who is a little more competent than him - within the zone of proximal development. By this way, teachers can somehow ensure the quality of given feedback.

\section{Recommendation}

Although this research has reached its goals, there are still limitations. First, since this is a case study which is aimed to undertake an in-depth view of what students actually do and think, the researcher only involved a small-size population that might limit the generalization of the result of this study. Second, the participants in this study are at an intermediate level and their language competence is not high enough to produce more qualified and diverse feedback. Future studies might expand to a larger number of participants and be conducted with upperintermediate or advanced levels to have an overall view on students' practice of feedback. 


\section{References}

Adams, R. (2007). Do second language learners benefit from interacting with each other. In A. Mackey (Ed.), Conversational interaction in second language acquisition, (pp. 29-51). Oxford, UK: Oxford University Press.

Askew, S., \& Lodge, C. (2000). Gifts, ping-pong and loops - Linking feedback and learning. In Feedback for learning (pp. 1-17). London, UK: Routledge Falmer.

Baleghizadeh, S., \& Abdi, H. (2010). Recast and its impact on second language acquisition. International Journal of Language Studies, 4(4), 57-68.

Black, P., Harrison, C., Lee, C., Marshall, B., \& Wiliam, D. (2004). Working inside the black box: Assessment for learning in the classroom. Phi Delta Kappan, 86(1), 8-21.

Boud, D., \& Falchikov, N. (2006). Aligning assessment with long-term learning. Assessment \& Evaluation in Higher Education, 31(4), 399-413.

Ellis, R. (2009). Corrective feedback and teacher development. L2 Journal, 1(1), 3-18.

Ellis, R., Loewen, S., \& Erlam, R. (2006). Implicit and explicit corrective feedback and the acquisition of 12 grammar. Studies in Second Language Acquisition, 28(2), 339-368.

Ellis, R., \& Sheen, Y. (2011). Corrective feedback in language teaching. In E. Hinkel (ed.), Handbook of research in second language teaching and learning (Vol. 2) (pp. 593-610). New York, NY: Routledge.

Ellis, R., \& Shintani, N. (2013). Exploring language pedagogy through second language acquisition research. Abingdon, UK: Routledge.

Foster, P., \& Ohta, A. S. (2005). Negotiation for meaning and peer assistance in second language classrooms. Applied Linguistics, 26(3), 402-430.

Fujii, A., \& Mackey, A. (2009). Interactional feedback in learner-learner interactions in a task based EFL classroom. IRAL-International Review of Applied Linguistics in Language Teaching, 47(3-4), 267-301.

Gielen, S., Peeters, E., Dochy, F., Onghena, P., \& Struyven, K. (2010). Improving the effectiveness of peer feedback for learning. Learning and Instruction, 20(4), 304-315.

Hall, G. (2016). Errors, corrective feedback and repair: Variations and learning outcomes. In A. Mackey, H. I. Park \& K. M. Tagarelli (Eds.), The Routledge handbook of English language teaching (pp. 517-530). Abingdon, UK: Routledge.

Kaufman, J. H., \& Schunn, C. D. (2011). Students' perceptions about peer assessment for writing: Their origin and impact on revision work. Instructional Science, 39(3), 387-406.

Kerr, P. (2017). Giving feedback on speaking. Retrieved October 20, 2018, from https://www.cambridge.org/us/files/4515/7488/5712/CambridgePapersinELT_Feedback OnSpeaking_2018_ONLINE.pdf

Koka, A., \& Hein, V. (2006). Perceptions of teachers' positive feedback and perceived threat to sense of self in physical education: A longitudinal study. European Physical Education Review, 12(2), 165-179. 
Łęska, K. (2008). Teachers' use of interaction patterns in a foreign language classroom and gains in students' oral fluency. Częstochowa, Poland: Wydawnictwo wyższej szkoły lingwistycznej.

Liu, N. F., \& Carless, D. (2006). Peer feedback: The learning element of peer assessment. Teaching in Higher Education, 11(3), 279-290.

Long, M. (1996). The role of the linguistic environment in second language acquisition. In W. C. Ritchie \& T. K. Bhatia (Eds.), Handbook of second language acquisition (pp. 413468). New York, NY: Academic Press.

Lu, J., \& Law, N. (2012). Online peer assessment: Effects of cognitive and affective feedback. Instructional Science, 40(2), 257-275.

Lynch, T. (2007). Learning from the transcripts of an oral communication task. ELT Journal, 61(4), 311-320.

Lyster, R. (1998). Negotiation of form, recasts, and explicit correction in relation to error typesand learner repair in immersion classrooms. Language Learning, 48(2), 183-218.

Lyster, R., \& Ranta, L. (1997). Corrective feedback and learner uptake: Negotiation of form in communicative classrooms. Studies in Second Language Acquisition, 19(1), 37-66.

Lyster, R., Saito, K., \& Sato, M. (2013). Oral corrective feedback in second language classrooms. Language Teaching, 46(1), 1-40.

Martin, L., \& Jacobs, M. (1980). Structured feedback delivered in small groups. Small Group Behavior, 11(1), 88-107.

Méndez, E. H., Cruz, R., \& del Rosario, M. (2012). Teachers' perceptions about oral corrective feedback and their practice in EFL classrooms. Profile Issues in Teachers' Professional Development, 14(2), 63-75.

Mutch, A. (2003). Exploring the practice of feedback to students. Active Learning in Higher Education, 4(1), 24-38.

Ohta, A. S. (2000). Rethinking interaction in SLA: Developmentally appropriate assistance in the zone of proximal development and the acquisition of L2 grammar. Sociocultural Theory and Second Language Learning, 4, 51-78.

Pili-Moss, D. (2014). The role and timing of corrective feedback in L2 discussion activities. International Journal of Pedagogy and Curriculum, 19(4), 53-62.

Preston, T. L., \& Todd-Mancillas, W. R. (1985). A grounded ethnographic inquiry into teacher oral feedback. Columbus, OH: ERIC Clearinghouse.

Reynolds, A. (2009). Why every student needs critical friends. Educational Leadership, 67(3), 54-57.

Richards, J. C., \& Lockhart, C. (1994). Reflective teaching in second language classrooms. Cambridge, UK: Cambridge University Press.

Richards, J. C., \& Schmidt, R. (2010). Longman dictionary of language teaching and applied linguistics (4th ed.). London, UK: Pearson. 
Roskams, T. (1999). Chinese EFL students' attitudes to peer feedback and peer assessment in an extended pairwork setting. RELC Journal, 30(1), 79-123.

Rubin, R. S. (2006). The academic journal review process as a framework for student developmental peer feedback. Journal of Management Education, 30(2), 378-398.

Sato, M. (2007). Modified output of Japanese EFL learners: Variable effects of interlocutor vs. feedback types. Ann Arbor, MI: ProQuest.

Sato, M., \& Ballinger, S. (2016). Peer interaction and second language learning: Pedagogical potential and research agenda. Amsterdam, Netherlands: John Benjamins Publishing Company.

Sato, M., \& Lyster, R. (2012). Peer interaction and corrective feedback for accuracy and fluency development: Monitoring, practice, and proceduralization. Studies in Second Language Acquisition, 34(4), 591-626.

Sayrs, L. (1998). Book review: Interviews: An introduction to qualitative research interviewing. American Journal of Evaluation, 19(2), 267-270. doi:10.1177/109821409801900217

Smith, K. (2009). From test takers to test makers. Educational Leadership, 67(3), 26-30.

Von Glasersfeld, E. (1991). A constructivist's view of learning and teaching. In R. Duit, F. Goldberg \& H. Niedderer (Eds.), Research in physics learning: Theoretical issues and empirical studies (pp. 29-39).

Von Glasersfeld, E. (1998). Cognition, construction of knowledge, and teaching. In Constructivism in science education (pp. 11-30). New York, NY: Springer.

Vygotsky, L. (1978). Zone of proximal development. In Mind in society: The development of higher psychological processes. Cambridge, MA: Harvard University Press

Wheldall, K., \& Merrett, F. (1984). Positive teaching: The behavioral approach. London, UK: Allen and Unwin.

Zhao, S. Y., \& Bitchener, J. (2007). Incidental focus on form in teacher - Learner and learner interactions. System, 35(4), 431-447. 